\title{
VICTIM-IMPACT STATEMENTS AT THE SENTENCING STAGE: GIVING CRIME VICTIMS A VOICE
}

\author{
PN Makiwane \\ BA(Hons) BProc LLB LLM LLD \\ Senior Lecturer, Walter Sisulu University, Mthatha
}

SUMMARY

The principle of proportionality seeks to limit, as far as possible, arbitrary punishment, and to achieve a balance by requiring courts to consider the sometimes competing interests of the state and the accused person. These competing interests have a missing link - the interests of the crime victim. Unless all relevant information is placed before court, including that of crime victims, the court will not arrive at a just punishment. There can be justice only when the interests of not only the offender and the state, but of the victim as well, are considered and balanced against one another. The introduction of victim-impact statements is one of the means by which the said balance may be achieved. Some of the established democracies have recognized the value of introducing victim-impact statements before the sentencing of offenders: South Africa might do well to follow in their footsteps. I believe that the use of these statements at appropriate stages of the trial would contribute to positive public perceptions about our criminal-justice system, and promote victim satisfaction with the criminal justice which is perceived by some to be heavily biased in favour of accused persons.

This paper seeks to highlight the plight of the crime victim within South Africa's criminal-justice system, and to add a voice to calls for the introduction of victimimpact statements during the sentencing stage in a criminal trial.

\section{$1 \quad$ INTRODUCTION}

The move towards victim-focused justice appears to be prevailing in contemporary thinking. This move is evident in the increased use of victimimpact statements by a number of countries ${ }^{1}$ - South Africa, sadly, is not among these countries. That so many jurisdictions have embraced the use of such statements suggests that there is a case for their acceptance in South Africa as well. As early as 1995 Naudé made a plea for the introduction of victim-impact statements in South Africa. ${ }^{2}$ In the United Kingdom Tony Blair, then the British Prime Minister, expressed the view that the criminal justice system must be "rebalanced in favour of crime victims."

Examples are New Zealand, Australia and almost all 50 states in the United States of America.

2 Naudé An International Perspective on Victim Participation in the Criminal Justice Process with Specific Reference to Victim-impact Statements (November 1995) 69-73. 
As a consequence, a Victim Personal-Statement Scheme was introduced, using perhaps a softer name in place of "victim-impact statement", in order to counter that country's strong opposition to any measures designed to provide space for victim participation within the criminal-justice system.

The half-hearted reception of victim-impact statements by some countries is to be deplored - these statements promote justice and will not, as is generally feared, necessarily interfere with the legitimate interests of accused persons. However, the prevailing view among lawyers is that crime victims have no role to play in the criminal process, the argument being that, were the victim allowed to participate in a meaningful way, "the delicate balance of the adversarial system would disintegrate, compromising the core interests of the system in preserving due process and arriving at a correct and dispassionate resolution of the case." 3

The fear referred to above cannot be used as a basis for denying crime victims the privilege of participation in the criminal-justice system. Their voice has to be heard because no one represents them - they do not regard the state as sufficiently representing their interests; courts may also not be adequately responsive to their needs. The defendant's right to speak at sentencing, on the other hand, is well entrenched in law. The exercise by the victim of the right to express the sometimes traumatic experience through impact statements would allow him/her to regain a sense of dignity, and reduce the feeling of powerlessness and shame. The offender would be confronted with the consequences of the offence, for which he should take full responsibility.

\section{THE CONCEPT "VICTIM-IMPACT STATEMENT"}

\section{What is a victim-impact statement?}

According to Erez, a victim-impact statement is an organized and structured method of ensuring that the court is aware of important information concerning the effect on the victim that the crime has had. ${ }^{4}$ It is a report presented to the presiding officer, usually in writing, following upon the conviction of the offender, but before he has been sentenced. ${ }^{5}$ The statement enables the crime victim, or a member of his/her family, an opportunity to make a statement to the court regarding the impact the crime has had on him/her. This at least provides some measure of assurance to the victim that he/she has been listened to and, probably, heard. That he/she played a role before the sentencing of the offender also makes him/her to feel less isolated. As Schuster has noted, the influence of victim-impact statements is, generally, not on sentence length or disposition; rather, it is on their "helping victims to reach emotional closure; bringing the humanity and

3 Sankoff and Wansbrough Is Three Really a Crowd? Thoughts about Victim-impact Statements and New Zealand's Revamped Sentencing Regime (2006) 1, http://www.isrcl.org/Papers/2006/Sankoff.pdf (accessed 2009-10-23).

4 Erez "Victim-impact Statements" in Grabowsky (ed) Trends and Issues in Crime and Criminal Justice (1991) 2.

5 See fn 7 below for New Zealand's definition. 
reality of the victim into the courtroom, educating the court, defendant and observers about a crime's personal toll ...."

A victim-impact statement is a report which informs the presiding officer of the impact or effects that the crime has had on the victim - this report usually includes the social, psychological, financial and physical impact of the crime. It enlightens the court on the trauma and loss suffered by the victim. In some jurisdictions the statement is presented in written form; in other jurisdictions even oral presentation is permitted. ${ }^{7}$ Although the victimimpact statement is commonly presented to the court prior to the sentencing of the accused, it is submitted that an impact statement can be used at any stage during the trial, as well as during bail proceedings. ${ }^{8}$ Such a statement can also be attached to the offender's file for consideration by the Parole Board when the prisoner's application for parole is submitted. The focus of this discussion is on the use of victim-impact statements in preparation for the sentencing of the offender.

\section{The history of victim-impact statements}

Victim-impact statements have been in use in some jurisdictions for more than three decades. ${ }^{9}$ The Community Law Reform Committee ${ }^{10}$ noted that these statements have long been in existence in criminal law, even though they were never referred to by this name. For example, it has been argued that if an accused is convicted of assault with intent to cause grievous bodily harm, the charge itself amounts to a victim-impact statement, and that "evidence of the harm caused may be used by the sentencing court in assessing the appropriate penalty to be imposed". ${ }^{11}$ This statement is, with respect, not accurate; at least not in the South African context.

What is referred to above is nothing other than ordinary evidence gathered during trial proceedings, and cannot be equated with a victimimpact statement. In the South African context it has been pointed out that section 274(1) of the Criminal Procedure $\mathrm{Act}^{12}$ is an invitation to crime

6 Schuster "Victim-impact Statements - Do They Make a Difference?" 2006 14(3) Watch Post 1.

7 S 22 of the [New Zealand] Victims' Rights Act, eg, defines a victim-impact statement as "information prepared for submission to, or submitted to, a judicial officer under ss 17 and 21 , including any recording, summary, transcript or other copy of information of that kind."

8 Montaldo Victim-impact Statements: An Important Tool (November 2009) 1, http://crime.about.com/od/victims/a/impact.htm (accessed 2009-10-12).

9 Garkawe The Effect of Victim-impact Statements on Sentencing Decisions (2006) 1.

10 Community Law Reform Committee of the Australian Capital Territory Report No. 6 Victims of Crime (1993) 3.

11 Erez 'Neutralising Victim Reform: Legal Professionals' Perspectives on Victim and Impact Statements" 1999454 Crime and Delinquency 520 523; and also see Sanders, Hoyle, Morgan and Cape ("Victim-impact Statements Don't Work, Can't Work" 2001 Criminal Law Review 447 454) who argue that witness statements taken for evidential purposes from doctors and other professionals sufficiently describe the harm and the trauma suffered. They contend that "most VIS [victim-impact statements] add little relevant information to the prosecution files that is not already available".

1251 of $1977 . S 274$ is intended to afford parties the opportunity to lead evidence in mitigation or aggravation of sentence, thereby enabling the court to arrive at the proper sentence. 
victims to inform the court of the impact of the crime. ${ }^{13}$ This statement is, with due respect, misleading for the following reasons:

(i) The section is about witnesses for both the defence and the state. A state witness is not necessarily a crime victim. Even if the victim gave the information under section 274(1), it would be in his/her capacity as a witness, and not as a victim.

(ii) Victim-impact statements, where allowed, are usually mandatory in that the court is expected to admit and consider them whenever the victim indicates a wish to present them. ${ }^{14}$ Section $274(1)$, on the other hand, is permissive, and allows the court at its discretion to receive evidence that might assist it in arriving at the appropriate sentence.

(iii) The section is, admittedly, wide enough to permit the introduction of victim-impact statements; however, it does not positively enjoin that victim-impact statements should be presented whenever the victim so wishes. The victim can, therefore, not initiate the introduction of victimimpact statements in terms of section 274(1).

(iv) While section 274(1) permits evidence to be led primarily viva voce, victim-impact statements are primarily presented in written or documented form. ${ }^{15}$

(v) The practice of receiving evidence in terms of section 274 has been in existence over some decades, long before the concept "victim-impact statement" was conceived. The section cannot, therefore, be construed as affording crime victims the right to present impact statements. ${ }^{16}$ Further, section 274(1) does not permit the introduction of every kind of information. The material that it accommodates is very limited and cannot amount to a victim-impact statement as we understand it.

Parties are called at the discretion of the presiding officer. For wording of $s$ 274(1) see fn 13 below.

13 S 274(1) provides that a court may "before passing sentence, receive such evidence as it thinks fit in order to inform itself as to the proper sentence to be imposed."

14 See s 13 of the Victims' Charter Act 175 of 2006 of the Australian State of Victoria, for example, which reads: "(1) A victim of a criminal offence may make a victim-impact statement to the court sentencing the person found guilty of the offence, and unless the court orders otherwise, that statement may be considered by the court in determining the sentence of the offender. (2) If a victim expresses a wish to make a victim-impact statement, a prosecuting agency should refer the victim to an appropriate victims'-services agency for assistance in preparing the victim-impact statement." However, in some jurisdictions victim-impact statements are allowed at the discretion of the sentencing officer (Beloof "Constitutional Implications of Crime Victims as Participants" 200388 Cornell Law Review 282 299).

15 See Naudé "Taking Victims to Court: A Call for Victim-impact Statements" 19935 Crime and Conflict 2222.

16 See $S v$ Bresler 19672 SA 451 (A). In that case the invitation to both prosecution and defence to place evidence before court evidence regarding sentence referred to what are generally known in law as evidence in aggravation and evidence in mitigation. It is submitted that this section should be used solely for this purpose, and not be "hijacked" for other purposes as this might create further confusion, cloud issues and retard the introduction of victim-impact statements into our criminal-justice system. 
Although international instruments of the United Nations initially focused on protecting the interests of criminal suspects, this body in due course realized that victims cannot be ignored entirely. Article $6(b)$ of the United Nations Declaration on Basic Principles of Justice for Victims of Crime and Abuse of Power (1985) ${ }^{17}$ provides that the "views and concerns of victims" should be presented and considered at appropriate stages of the proceedings where their personal interests are affected, "without prejudice to the accused ..." Although this article does not directly authorize the use of victim-impact statements at any stage during a criminal trial, it does not exclude their use either. In response to the United Nations Declaration referred to above and, recognizing that victim-impact statements could be a meaningful way by which victims' views and concerns can be expressed, some countries gradually introduced legislation designed to allow victim input before sentencing.

New Zealand, for example, introduced victim-impact statements through section 8(1) of the Victims of Offences Act. ${ }^{18}$ This Act permitted the use of victim-impact statements, but did not place a duty on judges to consider them. ${ }^{19}$ According to Cassell, forty-eight states in the United States of America guarantee, through state legislation, victims the right to be heard, in some form or another, at sentencing. The remaining two states allow victimimpact statements at the discretion of the sentencing judge. ${ }^{20} \mathrm{He}$ further notes that thirty-two states adopted victims' rights-amendments to their own constitutions, and that at federal level the country has the Crime Victims' Rights Act. ${ }^{21}$ With all the above examples South Africa cannot argue that it is impracticable to include the rights of crime victims in legislation. The Service Charter, discussed below, can never in its present form meaningfully address the interests of crime victims.

\section{The [South African] Service Charter for Victims of Crime [the Charter]}

The Charter was approved by the Cabinet towards the end of 2004. It was undoubtedly a late response to the United Nations Declaration referred to above, but remains an admirable initiative by the country. Clause 2 of the Charter provides crime victims with "the right to offer information". The content of this right includes the right to "make a statement to the court or give evidence during the sentencing proceedings to bring the impact of the crime to the court's attention" (author's own emphasis). The Charter has

17 Adopted by Resolution GA/RES/40/34 of 29 November 1985. This document, unfortunately, focuses more on service rights in setting out basic principles that member states must promote.

18173 of 1987.

19 Outtrim Victim Support in New Zealand: The Significance of the Relationship with the Police (1999) 14. The 1987 Act above was followed by the Victims' Rights Act 39 of 2002 which fully permitted the introduction of victim-impact statements for certain offences before the sentencing of offenders.

20 Cassell "In Defence of Victim-impact Statements" 20096 Ohio Journal of Criminal Law 611 615.

21 lbid. 
created space for victim-impact statements to be introduced into South Africa. It, unfortunately, does not place a duty on anyone to do anything, and provides no remedies should its provisions, or the minimum standards it sets, be undermined. It is a document with no enforcement mechanisms: it merely plots an ideal to which we should aspire. ${ }^{22}$ In short, although it may have moral force, it is not a legally binding document for the simple reason that it was never enacted by Parliament. Kelly comments: "[P]roviding rights without remedies would result in the worst of consequences, such as feelings of helplessness, lack of control and further victimization ... ultimately, with the victims' best interests in mind, it is better to confer no rights than rights without remedies." ${ }^{23}$ The rights of criminal suspects, on the other hand, are enshrined in the constitution.

The South African Law [Reform] Commission, in support of the introduction of victim-impact statements into legislation, concluded that "there is sufficient justification for the inclusion of a provision in the Sentencing Framework Bill which will formally recognize the use of victimimpact statements at the sentencing stage of the trial". ${ }^{25}$ It further proposed that the principles governing the treatment of crime victims should be contained in legislation. ${ }^{26}$ These proposals seem to have fallen on deaf ears.

Unless there is legislation that creates duties and remedies, all attempts to provide procedural rights for crime victims are destined to fail. Although no legislation can right the wrongs done to crime victims, legislation would shift the focus to the hitherto under-represented interests of victims, and give them a voice that must be heard. The effectiveness of the Charter only lies in providing service rights to crime victims - in the field of service rights there is undoubtedly discernible improvement. However, victim-impact statements fall squarely under procedural rights. Whether the "rights" contained in the Charter are rights is debatable - at best they can be referred to as victim interests.

\section{Who may present the victim-impact statement}

A victim-impact statement is usually presented by the primary victim, that is, someone who was directly affected by the offence, like the victim of rape or assault, or the victim's representative. The secondary victim, especially

22 Govender contends that the Charter sets aspirational standards for the criminal-justice system (Govender Giving Power to Victims of Crime (28 November 2007) 1, http://www.southafrica.info/services/rights/victimscharter-launch.htm (accessed 2009-0912).

23 Kelly "Victims" 198734 Wayne Law Review 6974.

24 See s 35 of the Republic of South Africa Constitution Act, 1996. Victims' complaints, according to the Charter, can be lodged either with the South African Human Rights Commission, the Office of the Public Protector, Commission on Gender Equality, Independent Complaints Directorate, Health Professions Council of South Africa, Metropolitan Police Offices or a lawyer of one's choice. A criminal suspect, on the other hand, can be provided with a lawyer at state expense.

25 South African Law [Reform] Commission Issue Paper 91 (Project 82) Sentencing (A New Sentencing Framework (2000) par 3.7.23.

26 Ibid. 
where the primary victim died or became incapacitated, or where the primary victim is a young child or a mentally-disadvantaged person, may present the statement in order to inform the court as to the impact the crime had on him or her. Although in practice most jurisdictions limit the "right" to present the statement to the primary victim, it is submitted that since the secondary victim is also a victim, he/she should be allowed to present the impact statement where the primary victim is unable to do so. Anyone who is disadvantaged by the offence may, therefore, be a victim for purposes of presenting the statement. ${ }^{27}$ It would be a waste of resources to permit presentation of impact statements for all types of offences. It would, for example, be a waste of time and resources to require a wealthy shop-owner to give such statement with respect to the impact that petty theft from his business had on him. ${ }^{28}$

\section{The purpose of a victim-impact statement}

Irrespective of the method through which it is presented, the impact statement could assist the presiding officer to arrive at a balanced decision because it enables him to understand the full impact the crime had on the victim - it presents a full picture of the circumstances surrounding the occurrence of crime. It provides courts with information that may be used in determining the appropriate sentence, provided it is reliable and relevant. According to Kelly, the provision of information on the harm increases proportionality and promotes accuracy in sentencing, and reminds judges that behind the state there is a real person with an interest in how the case is resolved. ${ }^{29}$ This promotes a perception that the justice system is fair because all parties, victim included, have been heard. If critics would appreciate the "increased proportionality" in sentencing that is referred to above, they would not be as averse to the idea of victim-impact statements being presented.

Without victim-impact statements, the defendant cannot always realize the extent of damage caused to the victim. If it is a charge of assault, the defendant's focus is on the injuries which he/she caused, not on the emotional and psychological aspects of what was done to the victim. The defendant often will not know the extent and impact of crime on the victim. If victim-impact statements are allowed, the defendant begins to realize how the victim was traumatised, and how the victim's parents or children were affected.

In $R v$ Piovia $^{30}$ the New Zealand High Court remarked that the use of victim-impact statements "shows what a major gap there was in the

27 The above does not mean everyone who is a victim should be allowed to present a victimimpact statement. To ensure that the category of crime victims does not become unwieldy, there may be a need to redefine the term "victim" for purposes of these statements.

28 It is my submission that victim-impact statements are appropriate for those crimes that presently attract minimum sentences, such as rape, murder, robbery and any crime that results in financial losses for the victim.

29 Kelly 198734 Wayne Law Review 73.

30 T032730, 19 March 2004, HC par 7, cited in Sankoff and Wansbrough 17. 
sentencing process in our criminal justice system before we had such reports. Judges sentenced people then without having the opportunity to see just how seriously the offending had affected the victims". Erez describes the purpose of the victim-impact statement as integration of the victim into the court process, and improving the quality of sentencing by balancing the rights of the accused against those of the crime victim. This integration, it is submitted, should always be voluntary.

\section{The disadvantages in the use of impact statements}

Those opposed to the use of victim-impact statements during the sentencing stage have always referred to the risk that the court may be negatively influenced by such statements, resulting in excessive penalties. In Payne $v$ Tennessee $^{31}$ the court cautioned:

"[T]he probative value of evidence is always outweighed by the prejudicial effect because of its inherent capacity to draw the jury's attention away from the character of the defendant and the circumstances of the crime to such illicit considerations as the eloquence with which family members express their grief and the status of the victim in the community."

This risk does not exist in South Africa because we do not have a jury system; further, the judges are capable of separating fact from fiction, reason from emotion, and cannot possibly allow themselves to be influenced by irrelevant considerations. The statements are, at any event, not intended to influence, but to inform, so that a balanced decision that takes into account the interests of both the offender and the victim is arrived at. As the American Bar Association stated: "Good decisions require good - and complete - information ... It is axiomatic that just punishment cannot be meted out unless the scope and nature of the deed to be punished is before the decision-maker."32

Despite any limitation that may be placed on the use of victim-impact statements, they continue to be important, ${ }^{33}$ providing, according to Sully $\mathrm{J}^{34}$ an "emotional catharsis" for crime victims. The Court in United States v Degenhardt ${ }^{35}$ correctly noted that even if a crime victim has nothing to say that would directly alter the court's sentence, "a chance to speak still serves important purposes ... victim allocution is both a rite and a right." Access to the court directly acknowledges that the victim, and no other, is the person that personally experienced victimhood. Giannini describes sentencing as one of the most public, formalized and ritualistic parts of a criminal case. By giving victims a "clear and uninterrupted voice at the moment on par with that of defendants and prosecutors, a right to allocate signals both society's

501 US 808 (1991) 846.

32 American Bar Association "Guidelines for Fair Treatment of Crime Victims and Witnesses" (1983) ABA Sec. Crim. Justice 1821.

33 Kirchengast "Sentencing Law and the 'Emotional Catharsis' of Victim's Rights in NSW Homicide Cases" 2008304 Sydney Law Review 614615.

34 In R v FD; R v FD; R v JD (2006) 160 A Crim R 392, cited in Kirchengast 2008304 Sydney Law Review 615.

35405 F. Supp. 2d 1341 (D. Utah) 20051349. 
recognition of victims' suffering and their importance to the criminal process". 36

Critics have argued that victim-impact statements are superfluous to the assessment of the accused's sentence. Sanders comments that significant harm is usually in the form of witness statements taken for evidential purposes from doctors and other professionals. Most victim-impact statements add little relevant information to prosecution files that is not already available. ${ }^{37}$

If victim-impact statements serve little or no purpose, as suggested above, why all the resistance to their introduction? Sanders' statement above, with respect, cannot coexist with the earlier statement that victim-impact statements may negatively influence presiding officers - if they add little, in what way can they influence presiding officers? Ashworth argues that if these statements do not influence, and are not intended to influence presiding officers, there is no purpose in their being presented at all. ${ }^{38}$

There are also concerns that the best interests of the crime victim are not served when he/she is required to present a victim-impact statement. ${ }^{39}$ These statements, it is argued, serve no purpose other than (i) to exploit the immense pain suffered by survivors of crime and (ii) as a lever to produce a heavy sentence. ${ }^{40}$ Erez and Rogers highlight the argument that victim input may have detrimental effects on the sentencing outcomes and processes. ${ }^{41}$ Further, the defendant often finds it difficult to rebut the statements from the victim, ${ }^{42}$ probably because the statements are often about the victim's psychological or mental condition which cannot be objectively verified. A more convincing argument is that any sentence must be founded on proved information.

Dubber, a strong critic of victim impact statements, concedes that victim impact evidence lays out before the offender the precise nature of his act, ideally in such a way as to permit and encourage him to identify with the victim's suffering as a person. He further notes that victim-impact evidence can help legitimize the process of punishment in the eyes of the offender "and perhaps even contribute to his recognition of himself as one person among others entitled to mutual respect and, in this sense, to [his]

36 Giannini "Equal Rights for Equal Rites?: Victim Allocution, Defendant Allocution and the Crime Victims' Rights Act" 2008 Yale Law \& Policy Review 431.

37 Sanders et al 2001 Criminal Law Review 447.

38 Ashworth "Victim-impact Statements and Sentencing" 1993 Criminal Law Review 498498 499.

39 This statement is not convincing, considering that victim-impact statements are presented by crime victims voluntarily - no one should be required to prepare and present a statement when he does not wish to do so.

40 Stevens "Victim-impact Statements Considered in Sentencing: Constitutional Concerns" 200822 California Law Review http://boalt.org/CCLR/v2/v2stevensnf.htm (accessed 200907-31) 1.

41 Erez and Rogers "Victim-impact Statements and Sentencing Outcomes and Processes: The Perspectives of Legal Professionals" 199939 The British Journal of Criminology 216217.

42 Stevens 2008 2(2) California Law Review http://boalt.org/CCLR/v2/v2stevensnf.htm (accessed 2009-07-31) 1. 
rehabilitation". ${ }^{43}$ Impact statements will further enable the defendant to empathize with the victim.

\section{RETRIBUTIVE JUSTICE AS AN IMPEDIMENT TO VICTIM INPUT}

The real reason for strong opposition to the use of victim-impact statements is rooted in history - the adversarial criminal trial is a contest between the state and the accused, with the presiding officer acting as a referee. Victimimpact statements are considered to be unrelated to the established purposes of punishment, ${ }^{44}$ to be subjective and emotion-loaded, and to have no bearing whatsoever on the blameworthiness of the offender. Stuart has noted that a criminal trial is about the just punishment, not about personal redress for victims. ${ }^{45}$ This statement is only true if the purposes of punishment are not subject to further development - there is in my view no reason why these purposes cannot be adjusted or extended to include personal redress for victims. Adherents to retributive justice will obviously not be moved by any form of persuasion - it is only those who accept that retributive justice can live side by side with restorative justice that will find space for victim involvement within the criminal processes.

The ideal aim of any criminal-justice system ought to be the promotion of justice for both the offender and the state, without ignoring victim interests. According to Artz and Quinét, the purpose of sentencing should not only be to limit the rights of the offender in accordance with the constitution but "also to balance the rights of the victim ... In determining the proportionate sentences when dealing with serious crimes [consideration] should be given to the harm the offence causes to the victim and not only harm to society" 46 (author's own emphasis).

Some of the critics express concern that victim-impact statements, if allowed, may satisfy the victim's need for retribution. The crime victim may, for example, exaggerate the impact of the crime, or even make unfounded allegations. This statement, it is submitted, equally applies with respect to an offender: to save himself from conviction, he may make false and exaggerated statements. ${ }^{47}$ Further, research has shown that crime victims are not excessively vindictive, ${ }^{48}$ and that a forgiving victim may, through a victim-impact statement, lessen the impact of the crime in order to gain a less severe penalty for the offender.

43 Dubber Victims in the War on Crime: The Use and Abuse of Victims' Rights (2002) 336.

44 For purposes of punishment see Terblanche Guide to Sentencing 2ed (2007) 155-171.

45 Stuart "Charter Protection against Law and Order, Victims' Rights and Equality Rhetoric" in Cameron (ed) The Charter's Impact on the Criminal Justice System (1996) 335. The standard argument is that a crime is a matter between the offender and the state; the victim has no role other than as a witness, and must seek redress in the appropriate forum, namely, the civil court where she can institute a claim for damages.

46 Artz and Quinét, Comments on Discussion Paper 91 Sentencing: A New Sentencing Framework 20002.

47 Garkawe The Effect of Victim-impact Statements on Sentencing Decisions (2006) 2.

48 According to Naudé, victims are not excessively punitive or vengeful, and generally do not desire heavy penalties for offenders (Naudé 19935 Crime and Conflict 22). 
Victims, it has been argued, are more interested in the restoration of the status quo ante, possibly through restitution or compensation. ${ }^{49}$ They are definitely not interested in punishment for the sake of inflicting pain on the offender. ${ }^{50}$ Our criminal justice system, more accustomed to retributive justice, often finds it difficult to integrate aspects of restorative justice which, if implemented, would meet the needs of both the offender and the victim. ${ }^{51}$ There can be no doubt that exercise of procedural rights, while advancing the cause of crime victims, inevitably encroaches on due process interests of criminal suspects and offenders. This insurmountable problem, in my view, should not be used as an excuse to exclude the victim, or to deny the victim the opportunity to give input before the offender is sentenced.

The adversarial nature of South Africa's justice system makes it difficult for victims to be accommodated within the criminal process. ${ }^{52}$ This, however, does not mean that the adversarial nature of our justice system excludes the possibility of affording victims a role. Undoubtedly, integrating victim interests into criminal processes is not an easy task, and will require change of attitude, empathy with the plight of victims and commitment from the police, the state and the courts in order to be a success. Beloof argues that it is no longer appropriate to evaluate criminal justice issues in terms of "due process" or "crime control" models. ${ }^{53}$ Fairness to the victim requires that his/her voice should be heard.

\section{WHAT DO VICTIMS STAND TO GAIN FROM IMPACT STATEMENTS?}

Criticisms levelled against the use of victim-impact statements during the sentencing stage ignore the therapeutic nature of these statements: victims enjoy the recognition that they have a role to play in the sentencing of offenders. ${ }^{54}$ Rubel argues that the effectiveness of sentencing will be increased if crime victims convey their feelings; that the process will become more democratic and reflective of the community's response to crime system. ${ }^{55}$ It is a statement that the criminal-justice system is sympathetic towards the victim, and that it understands her plea for justice. ${ }^{56}$ These statements increase the accuracy of information at the disposal of the presiding officer. The United States President's Task Force on Victims of

49 Frehsee "Restitution and Offender-Victim Arrangement in German Criminal law: Development and Theoretical Implications" 19993 Buffalo Criminal Law Review 325 325326.

50 Ibid.

51 Burton believes that retributive justice and retributive justice are not mutually exclusive (Burton "Empowerment and Retribution in Criminal and Restorative Justice" 1999 7(3\&4) Journal of Professional Ethics 111).

52 Booth "Delivering Justice to Victims of Crime" 2002401 Law Society Journal 64 64-65.

53 Beloof "The Third Model of Criminal Process: The Victim Participation Model" 1991 Utah Law Review 282289.

54 Rubel "Victim-participation in Sentencing Proceedings" 198628 Criminal Law Quarterly 226 237.

55 Corns "The Sentencing (Victim-impact Statements) Act" 199468 Law Institute Journal 1054 1057.

56 Ibid. 
Crime, arguing for victim-impact statements, notes that victims, no less than defendants, are entitled to their day in court, and to have their views considered. A judge, it continues, cannot evaluate the seriousness of a defendant's conduct without knowing how the crime has burdened the victim, and cannot reach an informed determination of the danger posed by a defendant without hearing from the person he has victimized. ${ }^{57}$ According to Corns, the use of victim-impact statements is a matter of basic fairness if the offender, the prosecution and non-victim witnesses are all heard by the court, why is the victim and her family not afforded the same opportunity ? $^{58}$

The benefits derived from the use of these statements before sentence is passed far outweigh the disadvantages. After all, when a cry for justice is made, it is not about justice to the offender, but to the offender, the community and his victim. Research indicates that a large percentage of crime victims support the use of victim-impact statements.

\section{CONCLUSION}

South Africa has been cautious, perhaps over-cautious, on the question of victim-impact statements. Naudé, correctly, contends that rights gained by the victim are rights lost to the defendant, probably implying that if the victim is allowed to express himself through a victim-impact statement, ${ }^{60}$ he inevitably introduces evidence that is detrimental to the interests of the offender. Meintjies-Van der Walt believes that if victim-impact statements were allowed, that would bring public pressure to bear on the courts, and that these statements may be "detrimental to the victim's psychological wellbeing."

While not under-playing the value of arguments advanced against the use of victim-impact statements at the pre-sentencing stage, the following views deserve consideration:

(i) Victim-impact statements contribute to procedural and substantive justice, and provide crime victims with an important component of procedural justice, namely, "the opportunity to present their case to the authorities before the decision is made" ${ }^{62}$

(ii) Fairness dictates that when the court hears from the offender or his lawyer, his family and friends, the person who has borne the brunt of the offender's crime should also be allowed to speak. ${ }^{63}$ Defendants are

57 The US President's Task Force Victims of Crime: Final Report (1982) 76-77.

58 Corns 199468 Law Institute Journal 1057.

59 Research in the United States of America, based on the survey of judges, indicates that four fifths are Concerned that victim-impact statements have some negative effect on sentence (Ashworth 1993 Criminal Law Review 502).

60 Naudé 19935 Crime and Conflict 22. Naudé, in his discussion, is advocating for, and not against, the introduction of victim-impact statements.

61 Meintjies-Van der Walt "Towards Victim Empowerment Strategies in the Criminal Justice Process" 1998 11(2) SACJ 157167.

62 Tyler "What is Procedural Justice: Criteria Used by Citizens to Assess the Fairness of Legal Procedure" 1998 22(1) Law Society Review 103107.

63 The US President's Task Force Victims of Crime: Final Report (1982) 77-78. 
allowed to speak before sentencing because this opportunity is critical to the legitimacy of the proceedings. ${ }^{64}$ It assures the appearance of justice and "provide[s] a ceremonial ritual at which society pronounces its judgment". ${ }^{65}$ By the same token, allowing victims the same opportunity assures perceived fairness. In other words, victim-impact evidence is appropriate not merely because defendants have the opportunity; rather, it is appropriate for the same reason as defendants get it. ${ }^{66}$ Emphasis has over centuries been placed on observance of due process for the accused person; is it not perhaps time to deliberately promote victim interests as well?

It is suggested that the possibility of victim-impact statements being introduced into our criminal-justice system should be seriously considered. Although the victim is a forgotten man in the criminal exchange, let us be reminded that it was in the name of victim rights that states were set up in the first place. ${ }^{67}$ Victim input, it has been held, may advance the various goals of sentencing: retribution, for example, is enhanced when the extent of the harm caused is disclosed so that the punishment meted out is measured against the level of harm caused. ${ }^{68}$

There is a case for victim-impact statements. A number of countries, including Australia, Canada and New Zealand, have led the way. By denying the victims the right to express their experiences as suggested above, our country has so far missed out on the opportunity to show that it cares for its crime victims. The Charter has failed dismally to address the problem; the country deserves nothing less than legislated victims' rights. Legislation is not intended to influence sentence, but to provide crime victims with a voice, whatever the impact may be on sentence. As the court stated in $R v$ Bullen: ${ }^{69}$ '[V]ictims' concerns, when denied expression in court, do not just fade away. The voices shut down in court are intensified in homes, in community gatherings and in the media."

64 Thomas "Beyond Mitigation: Towards a Theory of Allocution" 2007 Fordham Law Rev 2641 2678.

United States v Curtis 523 F.2d 1134 (D.C. App. 1975) 1135.

66 Cassell 20096 Ohio Journal of Criminal Law 625.

67 Pilon "Criminal Remedies: Restitution, Punishment or Both?" July 1978884 Ethics 348 348.

68 Erez 4.

69 (2001) 48 CR $\left(5^{\text {th }}\right) 110119$ (Yuk. Terr. Ct). 